\title{
MENINGKATKAN PENGUASAAN KOSAKATA BAHASA INGGRIS \\ DENGAN MENGGUNAKAN TRADITIONAL SONG DI MADRASAH \\ IBTIDAIYAH JAUHARUL ULUM SITUBONDO
}

\author{
Ach. Munawi Husein \\ Dosen FKIP Prodi PGSD Universitas Abdurrachman Situbondo \\ achmunawihusein@yahoo.com
}

\begin{abstract}
Abstrak : English is noticed as one of international languages which is very common to be used by people from different region and country to communicate each other. Nevertheless, the ability to use this language should develop during youth's school age. Students are often trapped by the very old-fashioned way of learning. They get bored even when they are not learning it. The research problem of this was "How is the use of Traditional song able to increase the fifth grade students' vocabulary mastery at MI Jauharul Ulum Locancang Panarukan Situbondo. The research objective was intended to find out how the using of Traditional song is able to increase the fifth grade students' vocabulary mastery at MI JAUHARUL ULUM Locancang Panarukan Situbondo. This research applied traditional song to increase students' vocabulary mastery. The result of vocabulary test in the first cycle showed that from 13 students there were only $8(61,54 \%)$ of them who got score $\geq 75$. This means that the test of the students did not achieve the target score. The result of vocabulary test in the second cycle showed that from 13 students, there were only 3 of them who get score $\leq 75$, so the test of them or $76,92 \%$ or 10 students got score $\geq 75$. This means that more students achieve the target score. The result of observation in Cycle II showed that the students' active participation improved during the lesson. There were 11 students or $84,62 \%$ actively involved in the teaching and learning process of vocabulary mastery through Traditional song. The rest 2 of 13 students were still categorized as passive students. It can be said that the observing in cycle 2 success because more than $75 \%$ students active in class. Based on the results above, it could be
\end{abstract}


concluded that the use of traditional song could improve the fifth grade students' vocabulary mastery.

\section{Key words: Vocabulary Mastery, Traditional Song.}

\section{PENDAHULUAN}

Bahasa Inggris adalah salah satu bahasa internasional yang lebih populer dibandingkan dengan bahasa- bahasa yang lain. Selain itu bahasa Inggris sangat umum digunakan oleh orang-orang dari daerah dan negara yang berbeda untuk berkomunikasi satu sama lain. Namun demikian, bahasa Inggris tidak digunakan sebagai bahasa keseharian di Indonesia sehingga kemampuan untuk menggunakan bahasa ini tergolong rendah. Untuk itu kemampuan berbahasa Inggris harus dikembangkan sejak dari Sekolah Dasar hingga Perguruan Tinggi. Siswa sering terjebak dalam pembelajaran yang sangat kuno. Mereka bosan dan menganggap bahasa Inggris adalah satu bahasa yang sangat sulit dan membosankan untuk dipelajari. Kosakata merupakan salah satu komponen bahasa yang harus diajarkan kepada siswa dalam belajar bahasa Inggris. Untuk meningkatkan penguasaan kosakata siswa, guru dapat menggunakan banyak media dan tekhnik yang menarik.

Tujuan pembelajaran Bahasa sebagaimana yang dinyatakan Enung Nur Aeni, M.Pd mengatakan bahwa bahasa terdiri dari empat aspek, yaitu, keterampilan mendengar, berbicara, membaca, dan menulis. Begitu juga dalam mempelajari bahasa Inggris, Firmansyah Diyata, M.Pd juga menyatakan bahwa ada empat keahlian yang idealnya harus dikuasai dalam pembelajaran Bahasa Inggris yaitu : speaking, reading, listening, dan writing. Dengan menguasai empat keahlian tersebut maka akan mempermudah tercapainya tujuan pembelajaran dan pencapain indikator dalam setiap materi pembelajaran bahasa Inggris yang ada.

Seseorang yang menguasai ke-empat aspek keterampilan bahasa itu juga

harus didukung dengan penguasaan kosakata yang baik. Penguasaan kosakata yang baik akan membuat orang memahami apa yang didengar, dibaca, ditulis dan apa yang diucapkan oleh orang lain. 
Kosakata atau dalam bahasa Inggris disebut dengan vocabulary, adalah salah satu komponen penting dalam berbahasa. Dengan menguasai vocabulary secara baik maka seseorang dapat menghubungkan empat keterampilan berbicara, mendengar, membaca dan menulis. Sebagaimana yang dinyatakan oleh Nunan bahwa, "kosa kata adalah bagian penting yang memudahkan dalam menggunakan bahasa kedua, karena tanpa sebuah kosa kata yang benar bahasa tidak akan dapat berfungsi secara struktur dan akan susah untuk dipahami." Maka jelaslah bahwa kosakata punya peran penting dalam berbahasa.

Ketika siswa SD mempelajari kosakata bahasa asing, siswa harus bisa dipusatkan perhatiannya. Memusatkan perhatian siswa bisa menggunakan ice breaking, lagu, dan lain-lain. Selain itu siswa SD akan dengan mudah menyerap materi pebelajaran ketika suasananya menyenangkan. Ketika siswa mempelajari kosakata asing, siswa harus merasa senang terlebih dahulu, paling tidak guru harus bisa membuat proses pembelajaran yang menyenangkan agar siswa mampu mengingat kosakata yang diajarkan dengan mudah dan tidak membosankan.

Beberapa faktor yang menjadi penyebab rendahnya penguasaan kosakata pada siswa kelas V di Madrasah Ibtidaiyah Jauharul Ulum Locancang yang ditunjukkan oleh gejala gejala sebagai berikut :

1. Dari hasil ulangan siswa di Bab sebelumnya mengenai Profession, ada sekitar $40 \%$ siswa yang belum menguasai kosakata tersebut.

2. Ketika siswa diberi pertanyaan spontan mengenai Season, rata-rata siswa hanya mampu menyebut kosakata Rainy dan Summer. Padahal ada banyak kosakata tentang Musim yang perlu mereka kuasai ditingkat itu.

3. Proses pembelajaran yang cenderung monoton.

Melihat kenyataan di atas, diketahui penyebab tidak tercapainya KKM disebabkan penggunaan metode yang tidak tepat. Oleh sebab itu penulis mencoba untuk menggunakan metode lain guna mengatasai masalah yang dihadapi siswa. Adapun metode yang dipilih adalah metode belajar sambil bermain dengan menggunakan media pengantar yaitu Traditional Song.

Traditional song yang dimaksud adalah peneliti menggunakan lagu tradisional di daerah sekitar yang akrab ditelinga siswa dan mengubahnya dengan 
menggunakan kosakata berbahasa inggris sesuai dengan materi yang relevan. Sebagai contoh, penulis menggunakan lagu "Ampar ampar pisang" yang sudah akrab ditelinga siswa dan mengubah liriknya dengan menggunakan materi tentang Season (musim).

Sebagaimana dikatakan Benyamin Franklin dalam Kalayo bahwa pembelajaran akan lebih mudah apabila siswa dilibatkan secara langsung dalam pembelajaran. Hal inilah yang meyakinkan penulis untuk menggunakan traditional song. Dengan menggunakan traditional song sebagai media pengantar sesuai dengan paparan di atas maka diharapkan akan dapat mengatasi masalah penguasaan kosakata pada siswa, sehingga siswa dapat menggunakan kosakata dalam setiap aspek berbahasa. Merujuk pada pernyataan -pernyataan di atas penulis tertarik untuk melakukan penelitian tindakan kelas dengan judul "Meningkatkan Penguasaan Kosakata Bahasa Inggris Dengan Menggunakan Traditional Song Pada Siswa Kelas V Di Madrasah Ibtidaiyah Jauharul Ulum Locancang Panarukan Situbondo.

\section{METODE}

Penelitian ini merupakan penelitian tindakan kelas (PTK) aau dikenal juga sebagai Classroom Action Research (CAR). PTK ini menggunakan model Kemmis dan Mc Taggart (Suharsimi Arikunto, 2006: 93). Model ini memliki empat tahap dalam satu siklus yaitu planning (perencanaan) Acting (tindakan), Observing (pengamatan), dan Reflecting (refleksi).

Penelitian Tindakan Kelas memiliki empat tahapan: perencanaan, bertindak, mengamati dan refleksi. persiapan dapat dilihat sebagai berikut: (a). Langkah-langkah pengajaran dalam prosedur tindakan, dan kegiatan dalam melaksanakan tindakan terhadap pemecahan yang telah direncanakan, (b) mempersiapkan media yang sesuai kebutuhan di kelas . (C) mempersiapkan lembar observasi, checklis dan rubric penialaian.

\section{PERENCANAAN}

Perencanaan adalah persiapan guru sebelum melakukan tindakan. Pada langkah ini peneliti mempersiapkan segala sesuatu untuk menyelesaikan kegiatan di kelas 
seperti merancang rencana pelajaran, merancang lagu tradisional, bahan ajar, observasi, checklist, rubrik penilaian. Dalam hal ini, peneliti berdiskusi dengan guru bahasa Inggris bila tindakan tersebut akan dimulai dan bagaimana cara terbaik untuk mengimplementasikan pencapaian kosakata dengan menggunakan lagu tradisional di kelas V. Peneliti dan guru bahasa Inggris membahas bahan yang cocok yang akan diberikan kepada siswa . Peneliti menyiapkan rencana pelajaran untuk proses belajar mengajar. Dalam penelitian ini, pelaksanaan tindakan telah dilakukan dalam tiga pertemuan dan setiap pertemuan dilakukan selama 90 menit.

Mempersiapkan strategi : Strategi mengajar menggunakan lagu tradisional dalam meningkatkan penguasaan kosakata adalah sebagai berikut.

1. Mempersiapkan Lagu tradisional

Sebelum siswa menonton video, guru mempersiapkan video terlebih dahulu, menentukan alokasi waktu.

2. Menonton Video Lagu tradisional

Guru menyuruh siswa untuk menonton video dan menirukan lagu yang ada di video.

3. Membahas video

Setelah siswa menonton video, guru berdiskusi dengan siswa apakah mereka mengerti apa yang telah mereka saksikan

Merancang RPP. Peneliti membuat rancangan pembelajaran sesuai dengan hasil diskusi dengan guru bahasa inggris. peneliti membuat rencana pembelajaran pada pertemuan pertama sampai ketiga.

Kriteria keberhasilan. Dalam penelitian tindakan kelas ini, kriteria keberhasilan adalah peningkatan yang telah dicapai oleh siswa menyangkut penguasaan kosakata. Kriteria adalah: 1. skor rata-rata siswa di tes kosakata dalam 'baik' Kategori (56-75). 2. Ada setidaknya 75\% dari siswa yang mendapat 75 sebagai nilai minimal standar. 3. Ada sekitar $75 \%$ dari siswa yang terlibat aktif dalam proses belajar mengajar penguasaan kosakata dengan menggunakan video yang kartun.

\section{Pelaksanaan}


Ketika semua persiapan sudah siap untuk dilaksanakan, peneliti menerapkan kegiatan yang telah dirancang menggunakan video yang kartun. Dalam melaksanakan kegiatannya, peneliti dibantu oleh seorang kolaborator yang pada saat yang sama bertindak sebagai pengamat dalam mengajar dan proses belajar di kelas. Selama proses tersebut, kolaborator melakukan pengamatan berdasar pada checklist dan catatan - catatan.

\section{Pengamatan Data dan sumber data.}

Data yang berupa data kualitatif dan kuantitatif. Data kualitatif adalah tentang partisipasi siswa dalam kosakata kegiatan, komentar, pendapat, dan saran. Data kuantitatif adalah tes kosakata siswa. Data diperoleh dari siswa dan guru berkolaborasi.

Instrumen dan teknik untuk pengumpulan data. Untuk mengumpulkan data yang dibutuhkan, peneliti menggunakan checklist observasi, catatan, daftar pertanyaan, dan tes. Checklist observasi digunakan untuk mengamati aktivitas siswa dalam proses belajar mengajar di kelas, dan untuk mengamati rencana pelajaran, materi pembelajaran, tes kosakata, dan proses pembelajaran yang berhubungan dengan pelaksanaan strategi menggunakan lagu tradisional . Indikator siswa aktif dapat dilihat pada mengajukan pertanyaan dan menjawab pertanyaan, memperhatikan selama pelajaran. Jika siswa memenuhi setidaknya tiga indikator mereka dikategorikan sebagai mahasiswa aktif. Penelitian ini berhasil jika sekitar $75 \%$ dari siswa aktif dalam mengajar dan proses kosakata pembelajaran dengan menggunakan strategi Cartoon Video.

\section{Refleksi}

Peneliti dan guru sebagai kolaborator melakukan kegiatan refleksi untuk mendapatkan hasil dari tindakan yang dikumpulkan dari observasi kelas dan tes kosakata dalam setiap pertemuan dengan teknik diskusi. refleksi dimaksudkan untuk mengetahui ada atau tidak adanya kelemahan pada kegiatan pengajaran dan untuk mengidentifikasi poin apa yang dilakukan dengan baik. Namun, hasil dari observasi kelas dan tes kosakata dalam siklus pertama dapat diketahui kekuatan dan kelemahan dari tindakan pada siklus pertama. Kemudian, informasi itu digunakan sebagai panduan untuk merevisi rencana pelajaran dari siklus pertama 
untuk menghasilkan rencana pelajaran untuk siklus kedua. Intinya adalah bahwa kelemahan direvisi untuk mengatur rencana pelajaran untuk siklus yang lebih baik, terutama berhubungan dengan proses belajar mengajar penguasaan kosakata dengan menggunakan lagu tradisional.

\section{HASIL}

\section{Hasil Observasi Siklus 1}

Berdasarkan pengamatan pertemuan pertama pada siklus 1 ada $61,54 \%$ atau 8 siswa berpartisipasi secara aktif dan 38,46\% atau 5 siswa berpartisipasi pasif dalam kegiatan belajar mengajar. Pertemuan kedua ada 69,23\% atau 9 siswa secara aktif berpartisipasi dan $30,77 \%$ atau 4 siswa berpartisipasi secara pasif dalam kegiatan belajar mengajar.

Berdasarkan hasil observasi pada pertemuan 1 dan pertemuan 2, dapat disimpulkan bahwa persentase partisipasi aktif siswa dalam siklus I adalah $65,38 \%$. Berdasarkan fakta tersebut, partisipasi aktif siswa tidak memenuhi persyaratan, yang setidaknya $75 \%$ dari subjek penelitian aktif berpartisipasi dalam proses belajar mengajar penguasaan kosakata menggunakan lagu tradisional.

\section{Hasil tes kosakata pada siklus 1}

Berdasarkan hasil tes kosakata, ditemukan bahwa persentase skor siswa dengan menggunakan lagu tradisional pada siklus I adalah 69,23\%. Seperti disebutkan sebelumnya, siklus penelitian ini dianggap berhasil jika skor utama dari siswa tes kosakata telah mencapai 75 atau lebih dan itu dicapai oleh setidaknya $75 \%$ dari total siswa. Ini berarti bahwa persyaratan persentase target dalam penelitian ini belum tercapai.

\section{Hasil Observasi Siklus 2}

Berdasarkan pengamatan, pada pertemuan pertama di siklus kedua ada $76,92 \%$ atau 10 siswa secara aktif berpartisipasi dan 23,08\% atau 3 siswa pasif berpartisipasi dalam kegiatan belajar mengajar. Partisipasi aktif siswa dalam siklus II meningkat. Hal ini terbukti dengan siswa sudah menunjukkan minat mereka dalam proses belajar mengajar penguasaan kosakata menggunakan lagu tradisional. Pengamatan dipertemuan kedua siklus kedua menunjukkan bahwa 
siswa yang berpartisipasi aktif sudah bertambah selama kegiatan belajar mengajar. Hasil penelitian menunjukkan bahwa ada 11 siswa atau 84,62\% secara aktif terlibat dalam proses belajar mengajar penguasaan kosakata melalui lagu tradisional dan sisanya 2 siswa atau 15,38\% (dari 13 siswa) masih belum aktif.

Data menunjukkan bahwa presentase kebutuhan 75\% dari keterlibatan aktif siswa dalam proses belajar mengajar penguasaan kosakata sudah terpenuhi. Dengan kata lain, mengajar penguasaan kosakata bahasa Inggris dengan menggunakan lagu tradisional berhasil. Dapat dikatakan bahwa siswa memberikan respon yang optimal.

\section{Hasil Vocabulary Test Cycle 2}

Berdasarkan hasil tes kosakata, ditemukan bahwa persentase skor dari penguasaan kosakata dengan menggunakan lagu tradisional pada siklus 2 yang mendapat 75 atau lebih adalah $78.46 \%$ artinya bahwa persyaratan persentase target dalam penelitian ini telah dicapai.

\section{DISKUSI}

Berdasarkan hasil pelaksanaan tindakan, penguasaan kosakata siswa umumnya dapat digambarkan sebagai berikut. Hasil tes kosakata dalam siklus pertama menunjukkan bahwa persentase siswa yang mendapat skor 75 atau lebih adalah $69,23 \%$ dan keterlibatan siswa dalam proses belajar mengajar adalah $65,38 \%$. Hal ini menunjukkan bahwa persentase subjek prestasi kosakata dan skor kebutuhan proses observasi pada siklus pertama dari penelitian ini belum tercapai dan dapat dikemukakakan bahwa pada siklus pertama belum berhasil. Untuk itu, peneliti mengamati penyebab masalah ini. Ditemukan bahwa siswa masih belum bisa mengikuti pengucapan lirik lagu berbahasa inggris karena siswa baru pertama kali mendengar kosa kata tersebut walaupun lagu yang digunakan sudah sering mereka dengar. Pada siklus 1, peneliti meminta mereka untuk mendengarkan lagu tentang season dengan menggunakan lagu ampar-ampar pisang dan meminta mereka untuk ikut bernyanyi setelah diperdengarkan lagu tersebut. Namun 
sebagian besar siswa masih belum aktif karena mereka masih belum percaya diri untuk menyanyikan lagu berbahasa Inggris. Mereka takut salah dalam pengucapan kosa kata berbahasa inggris tentang musim yang baru mereka dengar.

Pada siklus pertama yang sudah dilakukan, peneliti memutuskan untuk memperdengarkan kembali lagu tersebut dan mengajarkan cara membaca kosa kata tersebut satu persatu. Setelah itu peneliti mengajak dua orang siswa yang telah menguasai pengucapan kosakata tersebut dan bernyanyi bersama di depan. Sepertinya aktivitas sebelumnya tidak cukup efektif dan perlu diperkuat oleh kegiatan lain. Dari alasan ini peneliti melanjutkan pada siklus berikutnya, dalam siklus ini peneliti menggunakan media tambahan yaitu video dan teks tentang lagu tersebut sehingga memudahkan siswa dalam menyanyikan lagu tersebut dan lebih menarik dengan tampilan video tersebut. Setelah itu siswa diminta bernyanyi bersama. Pada siklus kedua inilah minat siswa untuk aktif dalam pembelajarn sudah mulai terlihat. Mereka tidak lagi malu untuk ikut bernyanyi dan bahkan sudah mulai hafal kosakata dari lagu tersebut. Setelah itu siswa diberi tugas berkaitan dengan materi tentang season. Pada siklus kedua inilah siswa memiliki peningkatan yang cukup signifikan. Para siswa mempunyai rasa percaya diri yang cukup tinggi, mereka mampu memotivasi diri mereka . Pada siklus II siswa lebih baik dalam memahami dari pada pada siklus pertama. Mereka dapat mengidentifikasi materi kosakata dengan menggunakan lagu tradisional. Jadi hasil prestasi kosakata pengujian siklus 2 menunjukkan perbaikan nilai siswa.

Berdasarkan hasil tes prestasi kosakata pada siklus kedua, kita mendapatkan gambaran, bahwa prestasi kosakata siswa pada siklus kedua jauh lebih baik dari pada periode sebelumnya. Hasil dari tes prestasi kosakata pada siklus kedua menunjukkan persentase siswa yang mendapat skor minimal 75 adalah $78.46 \%$. Selain itu rata-rata persentase keterlibatan siswa dalam proses belajar mengajar adalah $80,77 \%$. Ini berarti bahwa kebutuhan persen dari pencapaian kosa kata dan persyaratan standar skor pengamatan proses dalam siklus kedua dari penelitian ini telah dicapai dan dapat dikatakan penelitian 
dengan menggunakan metode ini ini dinilai sukses. Ini berarti bahwa lagu tradisional mampu meningkatkan prestasi kosakata siswa.

Hal ini di dukung oleh Daniel Schon dan kawan-kawan (2007: 2) dalam artikelnya mengungkapkan beberapa alasan mengapa lagu sangat baik untuk mempelajari bahasa. Pertama, secara emosional lagu dapat meningkatkan ketertarikan dan perhatian pada proses pembelajaran. Kedua, dari pandangan persepsi, penampakan kontur pitch meningkatkan pengelompokan fonologi, di mana perubahan suku kata sering dibersamai dengan pitch. Ketiga, konsistensi peta struktur musik dan linguistik dapat mengoptimalisasikan mekanisme proses pembelajaran. Hal ini karena dengan bernyanyi, peserta didik akan belajar tentang bahasa dengan mudah dan mereka akan terhibur dan bias menikmati lagu itu.

Dari pembahasan di atas, dapat disimpulkan bahwa lagu tradisional adalah media yang baik dalam mengajar dan belajar bahasa Inggris, terutama dalam mengembangkan prestasi kosakata siswa. Lagu Tradisional bisa membuat siswa merasa lebih rileks, lebih aktif, senang dan menikmati lagu tersebut.

\section{KESIMPULAN}

Penggunaan lagu tradisional dapat meningkatkan penguasaan kosa kata siswa kelas V di MI Jauharul Ulum Locancang panarukan Situbondo. Pada siklus pertama siswa masih tidak tertarik dengan lag tradisional dan mereka masih susah atas pelafalan kosakata Bahasa Inggris. Para siswa juga kehilangan semangat untuk belajar. Para siswa juga merasa tidak percaya diri dan takut keliru ketika mereka diperintahkan untuk mengajukan beberapa pertanyaan dari guru dan siswa tidak percaya diri untuk berbagi ide mereka. Dalam siklus ke 2, Para siswa dapat meningkatkan kepercayaan diri mereka, siswa dapat memotivasi diri dan mencoba untuk membangun pikiran positif. Pada siklus II siswa lebih baik dan lebih mudah memahami pada siklus pertama. mereka lebih aktif di kelas. Ini berarti bahwa dengan menggunakan lagu tradisional bisa menumbuhkan minat siswa dan membuat mereka lebih aktif. Peningkatan ini disebabkan oleh 
partisipasi siswa dalam setiap proses pembelajaran. Hal itu membuat para siswa lebih mudah untuk menghafal kosakata baru dalam Bahasa Inggris.

Oleh karena itu, dapat disimpulkan bahwa lagu tradisional sangat bernilai dan berguna untuk diterapkan dalam meningkatkan penguasaan kosakata siswa.

\section{SARAN}

Setelah melakukan kegiatan dalam meningkatkan penguasaan kosakata dengan menggunakan lagu tradisional, penulis ingin memberikan saran sebagai berikut: (1) lagu yang digunakan adalah lagu yang mudah untuk dimengerti oleh siswa. (2) Dalam rangka mendukung proses cara mengajar optimal, lebih baik bagi guru untuk memiliki media pembelajaran, misalnya video, gambar atau hal-hal nyata / objek untuk membantu para siswa untuk mendapatkan pemahaman yang lebih baik tentang bahan yang akan diajarkan.

\section{DAFTAR PUSTAKA}

Ali M. 1993. Strategi penelitian. Bandung : PT angkasa

Arikunto, S. 2006. Prosedur penelitian. Jakarta : PT rineka cipta

Brewster, J., Ellis, G. \& Girard, D. (2003). The Primary English Teacher's Guide. London: Penguin English.

Burhayani. (2013). The Effectiveness of Teaching Vocabulary through Songs to the Second Years Students of Ikatan Keluarga Kesejahteraan Tentara (IKKT) Elementary School West Jakarta.2nd International Seminar on Quality and Affordable Education (ISQAE 2013). Pg.69-73.

Cameron, L. (2001). Teaching Language to Young Learner. Cambridge: Cambridge University Press.

Eka Kurniasih. (2011). Teaching the Four Language Skills in Primary EFL Iskandar, Peneliatian Tindakan Kelas. Ciputat : PT Gaung Persada 